\title{
DE SENECTUTE CANTORUM
}

\section{By CARL VAN VECHTEN}

I

AM not sure," writes Arthur Symons in his admirable essay on Sarah Bernhardt, "that the best moment to study an artist is not the moment of what is called decadence. The first energy of inspiration is gone; what remains is the method, the mechanism, and it is that which alone one can study, as one can study the mechanism of the body, not the principle of life itself. What is done mechanically, after the heat of the blood has cooled, and the divine accidents have ceased to happen, is precisely all that was consciously skillful in the performance of an art. To see all this mechanism left bare, as the form of a skeleton is left bare when age thins the flesh upon it, is to learn more easily all that is to be learnt of structure, the art which not art but nature has hitherto concealed with its merciful covering."

Mr. Symons, of course, had an actress in mind, but his argument can be applied to singers as well, although it is safest to remember that much of the true beauty of the human voice inevitably departs with the youth of its owner. Still, style in singing is not noticeably affected by age and an artist who possesses or who has acquired this quality very often can afford to make lewd gestures at Father Time. If good singing depended upon a full and sensuous tone such artists as Ronconi, Victor Maurel, Max Heinrich, Ludwig Wullner, and Maurice Renaud would never have had any careers at all. It is obvious that any true estimate of their contribution to the lyric stage would put the chief emphasis on style, and this is usually the explanation for extended success on the opera or concert stage (as it explains Sarah Bernhardt's success in the drama) although occasionally an extraordinary and exceptional singer (I am thinking of Mme. Melba) may continue to give pleasure to her auditors, despite the fact that she has left middle age behind her, by the mere lovely quality of the tone she produces.

In the history of opera there may be found the names of many singers who have maintained their popularity and, indeed, a good deal of their art, long past fifty, and there is recorded at least one instance in which a singer, after a long absence from the 
theatre, returned to the scene of her earlier triumphs with her powers unimpaired, even augmented. I refer, of course, to Henrietta Sontag, born in 1805, who retired from the stage of the King's Theatre in London in 1830 in her twenty-fifth year and who returned twenty years later in 1849 . She had, in the meantime, become the Countess Rossi, but although she had abandoned the stage her reappearance proved that she had not remained idle during her period at retirement. For she was one of those artists in whom early "inspiration" counted for little and "method" for much. She was, indeed, a mistress of style. She came back to the public in Linda di Chaminoux and H. F. Chorley ("Thirty Years Musical Recollections") describes the occasion thus:

All went wondrously well. No magic could restore to her voice an upper note or two which Time had taken; but the skill, grace, and precision with which she turned to account every atom of power she still possessed-the incomparable steadiness with which she wrought out her composer's intentions-she carried through the part, from first to last, without the slightest failure, or sign of weariness-seemed a triumph. She was greeted - as she deserved to be-as a beloved old friend come home again, in the late sunnier days.

But it was not at the moment of Madame Sontag's reappearance that we could advert to all the difficulty which added to the honor of its success. She came back under musical conditions entirely changed since she left the stage- to an orchestra far stronger than that which had supported her voice when it was younger; and to a new world of operas. Into this she ventured with an intrepid industry not to be overpraised-with every new part enhancing the respect of every real lover of music. During the short period of these new performances at Her Majesty's Theatre, which was not equivalent to two complete Opera seasons, not merely did Madame Sontag go through the range of her old characters-Susanna, Rosina, Desdemona, Donna Anna, and the like-but she presented herself in seven or eight operas which had not existed when she left the stage-Bellini's Sonnambula, Donizetti's Linda, La Figlia del Reggimento, Don Pasquale; Le Tre Nozze, of Signor Alary, La Tempesta, by M. Halévy-the last two works involving what the French call 'creation', otherwise the production of a part never before represented. In one of the favourite characters of her predecessor, the elder artist beat the younger one hollow. This was as Maria, in Donizetti's La Figlia, which Mlle. Lind may be said to have brought to England, and considered as her special property. .......With myself, the real value of Madame Sontag grew, night after night - as her variety, her conscientious steadiness, and her adroit use of diminished powers were thus mercilessly tested. In one respect, compared with every one who had been in my time, she was alone, in right, perhaps, of the studies of her early days - as a singer of Mozart's music.

It was after these last London seasons that Mme. Sontag undertook an American tour. She died in Mexico. 
The great Mme. Pasta's ill-advised return to the stage in 1850 (when she made two belated appearances in London) is matter for sadder comment. Chorley, indeed, is at his best when he writes of it, his pen dipped in tears, for none had admired this artist in her prime more passionately than he. Here was a particularly good opportunity to study the bare skeleton of interpretative art; the result is one of the most striking passages in all literature:

Her voice, which at its best had required ceaseless watching and practice, had been long ago given up by her. Its state of utter ruin on the night in question passes description. She had been neglected by those who, at least, should have presented her person to the best advantage admitted by Time. Her queenly robes (she was to sing some scenes from Anna Bolena) in nowise suited or disguised her figure. Her hair-dresser had done some tremendous thing or other with her head-or rather had left everything undone. A more painful and disastrous spectacle could hardly be looked on. There were artists present, who had then, for the first time, to derive some impression of a renowned artist-perhaps, with the natural feeling that her reputation had been exaggerated. Among these was Rachel-whose bitter ridicule of the entire sad show made itself heard throughout the whole theatre, and drew attention to the place where she sat-one might even say, sarcastically enjoying the scene. Among the audience, however, was another gifted woman, who might far more legitimately have been shocked at the utter wreck of every musical means of expression in the singer-who might have been more naturally forgiven, if some humour of self-glorification had made her severely just-not worse-to an old prima donna;-I mean, Madame Viardot. Then, and not till then, she was hearing Madame Pasta. But Truth will always answer to the appeal of Truth. Dismal as was the spectacle-broken, hoarse, and destroyed as was the voicethe great style of the singer spoke to the great singer. The first scene was Ann Boleyn's duet with Jane Seymour. The old spirit was heard and seen in Madame Pasta's Sorgil and the gesture with which she signed to her penitent rival to rise. Later, she attempted the final mad scene of the opera-that most complicated and brilliant among the mad scenes on the modern musical stage- with its two cantabile movements, its snatches of recitative, and its bravura of despair, which may be appealed to as an example of vocal display, till then unparagoned, when turned to the account of frenzy, not frivolity-perhaps as such commissioned by the superb creative artist. By that time, tired, unprepared, in ruin as she was, she had rallied a little. When-on Ann Boleyn's hearing the coronation music for her rival, the heroine searches for her own crown on her brow-Madame Pasta turned in the direction of the festive sounds, the old irresistible charm broke out;-nay, even in the final song, with its roulades, and its scales of shakes, ascending by a semitone, the consummate vocalist and tragedian, able to combine form with meaning - the moment of the situation, whh such personal and musical display as form an integral part of operatic art-was indicated: at least to the apprehension of a younger artist. "You are right!" was 
Madame Viardot's quick and heartfelt response (her eyes were full of tears) to a friend beside her- "You are right! It is like the Cenacolo of Da Vinci at Milan-a wreck of a picture, but the picture is the greatest picture in the world!"

The great Mme. Viardot herself, whose intractable voice and noble stage presence inevitably remind one of Mme. Pasta, took no chances with fate. The friend of Alfred de Musset, the model for George Sand's "Consuelo", the "creator" of Fidès in Le Prophète, and the singer who, in the revival of Orphee at the Théatre Lyrique in 1859, resuscitated Gluck's popularity in Paris, retired from the opera stage in 1863 at the age of 43 , shortly after she had appeared in Alcestel (She sang in concert occasionally until 1870 or later). Thereafter she divided her time principally between Baden and Paris and became the great friend of Turgeniev. His very delightful letters to her have been published. Idleness was abhorrent to this fine woman and in her middle and old age she gave lessons, while singers, composers, and conductors alike came to her for help and advice. She died in 1910 at the age of $\mathbf{8 9}$. Her less celebrated brother, Manuel Garcia, (less celebrated as a singer; as a teacher he is given the credit of having restored Jenny Lind's voice. Among his other pupils Mathilde Marchesi and Marie Tempest may be mentioned) had died in 1906 at the age of 101 . Her sister, Mme. Malibran, died very young, in the early Nineteenth Century, before, in fact, Mme. Viardot had made her début.

Few singers have had the wisdom to follow Mme. Viardot's excellent example. The great Jenny Lind, long after her voice had lost its quality, continued to sing in oratorio and concert. So did Adelina Patti. Muriel Starr has told me of a parrot she encountered in Australia. The poor bird had arrived at the noble age of 117 and was entirely bereft of feathers. Flapping his stumpy wings he cried incessantly, "I'll fly, by God, I'll fly!" So many singers, having lost their voices, continue to croak, "I'll sing, by God, I'll sing!"

The Earl of Mount Edgcumbe, himself a man of personable age when he published his highly diverting "Musical Reminiscences", gives us some extraordinary pictures of senility on the stage at the close of the Eighteenth Century. There was, for example, the case of Cecilia Davies, the first English woman to sustain the part of prima donna and in that situation was second only to Gabrielli, whom she even rivalled in neatness of execution. Mount Edgcumbe found Miss Davies in Florence, unengaged and poor. A concert was arranged at which she 
appeared with her sister. Later she returned to England, too old to secure an engagement. "This unfortunate woman is now (in 1834) living in London in the extreme of old age, disease, and poverty," writes the Earl. He also speaks of a Signora Galli, of large and masculine figure and contralto voice, who frequently filled the part of second man at the Opera. She had been a principal singer in Handel's oratorios when conducted by himself. She afterwards fell into extreme poverty and, at the age of about seventy (!!!!), was induced to come forward to sing again at the oratorios:

I had the curiosity to go, and heard her sing $\mathrm{He}$ was despised and rejected of men in The Messiah. Of course her voice was cracked and trembling, but it was easy to see her school was good; and it was pleasing to observe the kindness with which she was received and listened to; and to mark the animation and delight with which she seemed to hear again the music in which she had formerly been a distinguished performer. The poor old woman had been in the habit of coming to me annually for a trifling present; and she told me on that occasion that nothing but the severest distress should have compelled her so to expose herself, which after all did not answer to its end, as she was not paid according to her agreement. She died shortly after.

In 1783 the Earl heard a singer named Allegranti in Dresden, then at the height of her powers. Later she returned to England and reappeared in Cimarosa's Matrimonio Segreto:

Never was there a more pitiable attempt; she had scarcely a thread of voice remaining, nor the power to sing a note in tune; her figure and acting were equally altered for the worse, and after a few nights she was obliged to retire and quit the stage altogether.

The celebrated Madame Mara, after a long sojourn in Russia, suddenly returned to England and was announced for a benefit performance at the King's Theatre after everybody had forgotten her existence:

She must have been at least seventy; but it was said that her voice had miraculously returned, and was as good as ever. But when she displayed these wonderfully revived powers, they proved, as might have been expected, lamentably deficient, and the tones she produced were compared to those of a penny trumpet. Curiosity was so little excited that the concert was ill attended.... and Madame Mara was heard no more. I was not so lucky (or so unlucky) as to hear these her last notes, as it was early in the winter, and I was not in town. She returned to Russia, and was a great sufferer by the burning of Moscow. After that she lived at Mitlau, or some other town near the Baltic, where she died at a great age, not many years ago. 
W. T. Parke, forty years principal oboist at Cávent Garden Theatre, is kinder to Mara in his "Musical Memoirs", but it must be taken into account that he is kinder to everybody else, too. There is little of the acrimonious or the fault-finding note in his pages:

That extrordinary singer of former days, Madame Mara, who had passed the last eighteen years in Russia, and who had lately arrived in England, gave a concert at the King's Theatre on the 6th of March (1820), which highly excited the curiosity of the musical public. On that occasion she sang some of her best airs; and though her powers were greatly inferior to what they were in her zenith, yet the same pure taste pervaded her performance. Whether vanity or interest stimulated Mara at her time of life to that undertaking, it would be difficult to determine; but whichsoever had the ascendency, her reign was short; for, by singing one night afterwards at the vocal concert, the veil which had obscured her judgment was removed, and she retired to enjoy in private life those comforts which her rare talent had procured for her.

Parke, in his "Memoirs," speaks of a Mrs. Pinto, "the once celebrated Miss Brent, the original Mandane in Arne's Artaxerxs es," who appeared in $\mathbf{1 7 8 5}$ at the age of nearly seventy in Milton'Mask of Comus at a benefit for a Mr. Hull, "the respectable stagemanager of Covent Garden Theatre." She was to sing the song of "Sweet Echo" and as Parke was to p'ay the responses to her voice on the oboe he repaired to her house for rehearsal:

Although nearly seventy years old, her voice possessed the remains of those qualities for which it had been so much celebrated,power, flexibility, and sweetness. On the night Comus was performed she sang with an unexpected degree of excellence, and was loudly applauded. This old lady, as a singer, gave me the idea of a fine piece of ruins, which though considerably dilapidated, still displayed some of its original beauties.

La Camargo, the favorite dancer of Paris in the early Eighteenth Century, the inventor, indeed, of the short ballet skirt, and the possessor of many lovers, retired from the stage in $\mathbf{1 7 5 1}$ with a large fortune, besides a pension of fifteen hundred francs. Thenceforth she led a secluded life. She was an assiduous visitor to the poor of her parish and she kept a dozen dogs and an Angora cat, which she overwhelmed with affection. In that quaint book, "The Powder Puff," by Franz Blei, you may find a most charming description of a call paid to the lady in $\mathbf{1 7 6 8}$ in her little old house in the Rue St. Thomas du Louvre, by Duclos, Grimm, and Helvetius, who had come to ask her, in bantering mood, whom, in her past life, she had loved best. Her answer touched these men, who took their leave. "Helvetius told Camargo's story to his 
wife; Grimm made a note of it for his Court Journal; and as for Duclos, it suggested some moral reflections to him, for when, two years li ar, Mle. Marianne Camargo was carried to her grave, he remarked: 'It is quite fitting to give her a white pall like a virgin." "

Sophie Arnould, one of the most celebrated actresses and singers of the Eighteenth Century, died in poverty at the age of 63 and there is no record of her burial place. She had been the friend of Voltaire, Rousseau, d'Alembert, Diderot, Helvetius, and the Baron d'Holbach. She had "created" Gluck's Iphigénie en Aulide and the composer had said of her, "If it had not been for the voice and elocution of Mlle. Arnould my Iphigénie would never have been performed in France." In her youth she had interested not only Marie Antoinette but also the king and she had been the object of Mme. de Pompadour's suspicion and Mme. du Barry's rage. Garrick declared her a better actress than Clairon. She was as famous for her wit as for her singing and acting. When Mme. Laguerre appeared drunk in Iphigénie en Tauride she exclaimed, "Why, this is Iphigenie en Champagne l" Indeed, she made so many remarks worthy of preservation that shortly after her death in 1802 a book called "Arnoldiana", devoted to her epigrams, was issued. Nevertheless this lady was hissed at the age of 36 when, after a short absence from the stage, she reappeared as Iphigénie in 1776. She was neither old nor ugly and if her voice may have lost something her nineteen years of stage life in Paris might have weighed against that. On one occasion, according to La Harpe, when she had the line to sing, "You long for me to be gone," the audience applauded vociferously. To protect Sophie, Marie Antoinette sat in a box on several nights and stemmed the storm of disapproval, but in the end even the presence of the queen herself was insufficient to quell the hissing. One sad story completes the picture. In 1785, when her financial troubles were beginning, her two sons, who bore her no love, called for money. She had none to give them. "There are two horses left in the stable," she said. "Take those." They rode away on the horses.

Latin audiences are notoriously unfaithful to their stage favorites. In "The Innocents Abroad" Mark Twain tells us of the bad manners of an Italian audience. The singer he mentions is Erminia Frezzolini, born at Orvieto in 1818. She sang both in England and America. Chorley said of her:

She was an elegant, tall woman, born with a lovely voice, and bred with great vocal skill (of a certain order); but she was the first who arrived of the 'young Italians' - of those who fancy that driving 
the voice to its extremities can stand in the stead of passion. But she was, nevertheless, a real singer, and her art stood her in stead for some years after nature broke down. When she had left her scarce a note of her rich and real soprano voice to scream with, Madame Frezzolini was still charming.

She died in Paris, November 5, 1884. Now for Mark Twain:

I said I know nothing about the upper classes from personal observation. I must recall it. I had forgotten. What I saw their bravest and their fairest do last night, the lowest multitude that could be scraped out of the purlieus of Christendom would blush to do, I think. They assembled by hundreds, and even thousands, in the great Theatre of San Carlo, to do-what? Why, simply to make fun of an old womanto deride, to hiss, to jeer at an actress they once worshipped, but whose beauty is faded now, and whose voice has lost its former richness. Everybody spoke of the rare sport there was to be. They said the theatre would be crammed because Frezzolini was going to sing. It was said she could not sing well now; but then the people liked to see her, anyhow. And so we went. And every time the woman sang they hissed and laughed - the whole magnificent house-and as soon as she left the stage they called her on again with applause. Once or twice she was encored five and six times in succession, and received with hisses when she appeared, and discharged with hisses and laughter when she had finished -then instantly encored and insulted again! And how the high-born knaves enjoyed it! White-kidded gentlemen and ladies laughed till the tears came, and clapped their hands in very ecstasy until that unhappy old woman would come meekly out for the sixth time, with uncomplaining patience, to meet a storm of hisses! It was the cruellest exhibition-the most wanton, the most unfeeling. The singer would have conquered an audience of American rowdies by her brave, unflinching tranquillity (for she answered encore after encore, and smiled and bowed pleasantly, and sang the best she possibly could, and went bowing off, through all the jeers and hisses, without ever losing countenance or temper); and surely in any other land than Italy her sex and her helplessness must have been an ample protection for her-she could have needed no other. Think what a multitude of small souls were crowded into that theatre last night!

English audiences, on the other hand, are notoriously friendly to their old favorites. When Dr. Hanslick, the Viennese critic, visited England and heard Sims Reeves singing before crowded houses as he had been doing for forty or fifty years, he remarked, "It is not easy to win the favor of the English public; to lose it is quite impossible."

Mme. Grisi made her last appearance in London in 1866 at the theatre she had left twenty years previously, Her Majesty's. The opera was Lucrezia Borgia. At the end of the first act she miscalculated the depth of the apron and the descending curtain left her outside, on her knees. She had stiffness in her 
joints and was unable to rise without assistance. The situation must have been very embarrassing to a singer who previously had been an idol of the public. In the passionate duet with the tenor she made an unsuccessful attempt to reach the $A$ natural. Notwithstanding the fact that she was well received and that she got through the greater part of the opera with credit, her impressario, J. H. Mapleson, relates in his "Memoirs" that after the final curtain had fallen she rushed to tell him that it was all over and that she would never appear again.

German audiences, too, are kind to their favorites. In America we adopt neither the attitude of the English and Germans, nor yet that of the Italians and French. We simply stay away from the theatre. Mark Twain has put it succinctly: "When a singer has lost his voice and a jumper his legs, those parties fail to draw."

Benjamin Lumley in his "Reminiscences of the Opera", quoting an anonymous friend, relates a touching story regarding Catalani, who was born in 1779 and who retired from the stage in 1831. When Jenny Lind visited Paris in the spring of 1849 she learned to her astonishment that Catalani was in the French capital. The old singer, who resided habitually in Florence, had come to Paris with her daughter, who, as the widow of a Frenchman, was obliged to go through certain legal forms before taking possession of her share of her husband's property. Through a friend of both ladies it was arranged that the two should meet at a dinner at the home of the Marquis of Normandy, the English ambassador to the Tuscan court, but the Swedish singer could not restrain her impatience and before that event she set out one forenoon for Mme. Catalani's apartment in the Rue de la Paix and sent in her name by a servant. The old singer hastened out to greet her distinguished visitor with obvious delight. She had known nothing of Mlle. Lind's presence in Paris and had feared that such a chance would never befall her, much as she had longed to see the celebrated singer who had excited the English public in a way which recalled her own past triumphs. They talked together for an hour. At the dinner the Marchioness of Normandy considerately refrained from asking Jenny Lind to sing because no one is allowed to refuse such an invitation made by a representative of royalty. Catalani, however, had no such scruples. She went up to the Nightingale and begged her to sing, adding, "C'est la vieille Catalani qui desire vous entendre chanter, avant de mourir!" This appeal was irresistible. Jenny Lind sat down to the piano and sang Non credea mirarti and one or two other 
airs, including $A h /$ non giunge. Catalani is described as sitting on an ottoman in the centre of the room, rocking her body to and fro with delight and sympathy, murmuring, "Ah! la bella cosa che la musica, quando si fà di quella maniera!" and again "Ah! la carissima! quanto bellissima!" A dinner at Catalani's anartment followed, but a few days later it became known that the old singer was ill, an illness which proved fatal. She had, however, heard the Swedish Nightingale sing "avant de mourir."

William Gardiner visited Madame Catalani in 1846:

I was surprised at the vigour of Madame Catalani, he says, and how little she has altered since $I$ saw her in Derby in 1828. I paid her a compliment on her good looks. 'Ah', said she, 'I'm grown old and ugly.' I would not allow it. 'Why, man,' she said, 'I'm sixtysix!' She has lost none of that commanding expression which gave her such dignity on the stage. She is without a wrinkle, and appears to be no more than forty. Her breadth of chest is still remarkable; it is this which endowed her with the finest voice that ever sang. Her speaking voice and dramatic air are still charming, and not in the least impaired.

Is Christine Nilsson still alive? I think so. She was born August 20, 1843. ' In Clara Louise Kellogg's very entertaining, but not always trustworthy, "Memoirs" there is an interesting reference to this singer in her later career. Dates, unfortunately, are not furnished.

I was present, declares Mme. Kellogg, on the night...when she practically murdered the high register of her voice. She had five upper notes the quality of which was unlike any other I ever heard and that possessed a peculiar charm. The tragedy happened during a performance of The Magic Flute in London. . . Nilsson was the Queen of the Night, one of her most successful early rôles. The second aria in The Magic Flute is more famous and less difficult than the first aria, and, also, more effective. Nilsson knew well the ineffectiveness of the ending of the first aria in the two weakest notes of a soprano's voice, A natural and B flat. I never could understand why a master like Mozart should have chosen to use them as he did. There is no climax to the song. One has to climb up hard and fast and then stop short in the middle. It is an appalling thing to do and that night Nilsson took those two notes at the last in chest tones. 'Great heavens!' I gasped, 'what is she doing? what is the woman thinking of!' Of course I knew she was doing it to get volume and vibration and to give that trying climax some character. But to say that it was a fatal attempt is to put it mildly. She absolutely killed a certain quality in her voice there and then and she never recovered it. Even that night she had to cut out the second great aria. Her beautiful high notes were gone forever.

As I have said, the date of this incident, which is not recorded elsewhere, is not mentioned, but Christine Nilsson sang in New 
York in the early eighties and continued to sing until 1891, the year of her final appearance in London.

Adelina Patti, born the same year as Nilsson, but six months before (February 10, 1843) made many farewell tours of this country-one too many in 1903-4, when she displayed the beaux restes of her voice. She is living at present in retirement at Craig-y-Nos in Wales. Her greatest rival, Etelka Gerster, too, is alive, I believe.

Lilli Lehmann, one of the oldest of the living great singers, was born May 13, 1848. She was a member of the famous casts which introduced many of the great Wagner works to New York. Her last appearances in opera here were made, I think, in the late nineties, but she has sung here since in concert and in Germany she has frequently assisted at the performances of the Mozart festivals at Salzburg and has even sung in Norma and Götterdämmerung within recent years! Her head is now crowned with white hair and her noble appearance and her magnificent style in singing have doubtless stood her in good stead at these belated performances, which probably were disappointing, judged as vocal exhibitions.

Lillian Nordica had a long career. She was born May 12, 1859, and made her operatic début in Brescia in La Traviata in 1879. She continued to sing up to the time of her death in $\mathbf{B a -}$ tavia, Java, May 10, 1914. Indeed, she was then undertaking a concert tour of the world at the age of 55! But the artist who in the nineties had held the Metropolitan Opera House stage with honor in the great dramatic rôles, had very little to offer in her last years. Never a great musician, defects in style began to make themselves evident as her vocal powers decreased. Her season at the Manhattan Opera House in 1907-8 was quickly and unpleasantly terminated. A subsequent single appearance as Isolde at the Metropolitan in the winter of 1909-10 was even less successful. The voice had lost its resonance, the singer her appeal. Her magnificent courage and indomitable ambition urged her on to the end.

Two singers whose voices have been miraculously preserved, who have indeed suffered little from the ravages of time, are Marcella Sembrich and Nellie Melba. Both of these singers, however, have consistently refrained from misusing their voices (if one may except the one occasion on which Mme. Melba attempted to sing Brinnhilde in Siegfried with disastrous results). Mme. Melba (according to Grove's Dictionary, which like all other books devoted to the subject of music, is frequently 
inaccurate) was born in Australia, May 19, 1859. Therefore, she was 28 years old when she made her début in Brussels as Gilda on October 12, 1887. She has used her voice carefully and well and still sings in concert and opera at the age of 58 . With age, indeed, her voice has taken on color. When she last sang here in opera at the Manhattan Opera House in 1906-7 she was in her best vocal estate. Her voice, originally rather pale, had become mellow and rich, although it is possible it had lost some of its old remarkable flexibility. When last $I$ heard her in concert a few years ago at the Hippodrome it seemed to me that I had never before heard so beautiful a voice, and yet Mme. Melba sang in the first performance of opera I ever attended (Chicago Auditorium; Faust; February 22, 1899). ${ }^{2}$

Marcella Sembrich was born February 15, 1858. She made her début in Athens in I Puritani, June 3, 1877, and she made her New York début in Lucia October 24, 1883, at the beginning of the first season of the Metropolitan Opera House. After a long absence she returned to New York in $\mathbf{1 8 9 8}$ as Rosina in Il Barbiere. After that year she sang pretty steadily at the Metropolitan until February 6, 1909, when she bid farewell to the New York opera stage in acts from several of her favorite operas at the age of 51 (or lacking nine days of it). She subsequently sang in a few performances of opera in Europe and was heard in song recital in America. When she left the opera house she had no rival in vocal artistry; and she had so entirely solved the problems of style in singing certain kinds of songs that she also surveyed the field of song recital from a mountain top. But such a singer as Mme. Sembrich, who made her appeal through the expression of the milder emotions, who never, indeed, attempted to touch dramatic depths, even style, in the end, will not assist. Magnificent Lilli Lehmann might make a certain effect in

'Nellie Melba made a belated and unfortunate attempt to sing Margueirte in Fauat with the Chicago Opera Company, Monday evening. Pebruary 4. 1918, at the Lexington Theatre, in New York. She sang with some art and style. Purity of tone and extraordinarily clear enunciation were still features of her performance but scarcely a shadow of the beautiful voice remained. As if to make up for absence of voice the singer made histrionic efforts such as she had never deemed necessary at the height of her career. She made a serious attempt to avoid conversation with Faust in the Kermesse'scene; she almost danced the jewel song and embraced the tenor with passion in the love duet. Her acting in the church scene was nearly convincing. Terrified by Méphistophelès she flung her prayer book across the stage. She groaned dismally over the death of Valentine. Her personal appearance was shockingly inappropriate, of course, and the first lines of Marguerite's part, "Non monsieur, je ne suis demoiselle, ni belle" had a merciless application. . . Mme. Melba made a second appearance in the same part, Thursday evening, February 14. I was not present on this occassion. According to H. T. Finck, Mr. Caruso once said, "When you hear that an artist is going to retire, don't you believe it, for as long as he keeps his voice he will sing. You may depend upon that." Sometimes longer! 
Götterdämmerung as long as she had a leg to stand on or a note to croak, but an adequate delivery of Der Nussbaum or Wie Melodien demands a vocal control which a singer past middle age is not always sure of possessing. After a long retirement Mme. Sembrich gave a concert at Carnegie Hall, November 21, 1916. The house was crowded and the applause at the beginning must almost have unnerved the singer, who walked slowly to the front of the platform as the storm burst and then bowed her head again and again. Her programme on this occasion was not one of her best. She had not chosen familiar songs in which to return to her public. This may in a measure account for her lack of success in always calling forth steady tones. However, on the whole, her voice was amazingly fresh. Her high notes especially rang true and sounded as resonant as ever. Her middle voice showed wear. Her style remained impeccable, unrivalled. She announced, following this concert, a series of four recitals in a small hall and actually appeared at one of them. This time I did not hear her, but $I$ am told that her voice refused to respond to her wishes. Nor was the hall filled. The other concerts were abandoned. "Mme. Sembrich has never been a failure and she is too old to begin now!" she is reported to have said to a friend.

Emma Calvés date of birth is recorded as 1864 in some of the musical dictionaries. This would make her 53 years old. Her singing of La Marseillaise a year ago at the Allies Bazaar at the Grand Central Palace proved to me that her retirement from the opera was premature. Her performances at the Manhattan Opera House in 1906-7 were memorable, vocally superb. Her Carmen was out of drawing, dramatically, but her Santuzza and her Anita remained triumphs of stage-craft.

Emma Eames, born August 13, 1867, is three years younger than Mme. Calvé. She made her début as Juliette, March 13, 1899. She retired from the opera stage in 1907-8, although she has sung since then a few times in concert. Her last appearances at the Opera were made in dramatic rôles, Donna Anna, Leonora (in Trovatore), and Tosca, in contradistinction to the lyric parts in which she gained her early fame. That she was entirely successful in compassing the breach cannot be said in all justice. Yet there was a certain distinction in her manner, a certain acid quality in her voice, that gave force to these characterizations. Certainly, however, no one would ever have compared her Donna Anna favorably with her Countess in Figaro. Her performance of Or sai chi l'onore was deficient in breadth of 
style and her lack of breath control at this period gave uncertainty to her execution.

Life teaches us, through experience, that no rule is infallible, but in so far as $I$ am able to give a meaning to these rambling biographical notes, collected, I may as well admit, more to interest my reader than to prove anything, it is the meaning, sounded with a high note of truth by Arthur Symons, in the paragraph quoted at the beginning of this essay. Style is a rare quality in a singer. With it in his possession an artist may dare much for a long time. Without it he exists as long as those qualities which are perfectly natural to him exist. A voice fades, but a manner of applying that voice (even when there is practically no voice to apply) to an artistic problem has an indefinite term of life. 